
\title{
25 Research Soure \\ Persistence of Ecologically Similar Fungi in a Restricted Floral Niche
}

\author{
Vuledzani O. Mukwevho
}

Stellenbosch University

Léanne L. Dreyer

Stellenbosch University

Francois Roets ( $\nabla$ fr@sun.ac.za )

Stellenbosch University https://orcid.org/0000-0003-3849-9057

\section{Research Article}

Keywords: Fungal diversity, Inter-species competition, Knoxdaviesia, Spore-vector, Sporothrix

Posted Date: January 18th, 2022

DOI: https://doi.org/10.21203/rs.3.rs-1067109/v1

License: (1) This work is licensed under a Creative Commons Attribution 4.0 International License. Read Full License

Version of Record: A version of this preprint was published at Antonie van Leeuwenhoek on April 7th, 2022. See the published version at https://doi.org/10.1007/s10482-022-01732-w. 


\section{Abstract}

Fungi in the genera Knoxdaviesia and Sporothrix dominate fungal communities within Protea flowerheads and seed cones (infructescences). Despite similar ecologies, they show strong host recurrence and often occupy the same individual infructescence. Differences in host chemistry explain their host consistency, but the factors that allow co-occupancy of multiple species within individual infructescences are unknown. Sporothrix splendens and K. proteae often grow on different senescent tissue types within infructescences of their $P$. repens host, indicating that substrate-related differences aid their co-occupancy. Sporothrix phasma and $K$. capensis grow on the same tissues of $P$. neriifolia suggesting neutral competitive abilities. Here we test the hypothesis that differences in host-tissues dictate competitive abilities of these fungi and explain their co-occupancy of this spatially restricted niche. Media were prepared from infructescence bases, bracts, seeds, or pollen presenters of $P$. neriifolia and $P$. repens. As expected, $K$. capensis was unable to grow on seeds whilst $S$. phasma could. As hypothesised, $K$. capensis and S. phasma had equal competitive abilities on pollen presenters, explaining their co-occupancy of this resource. Growth of $K$. proteae was significantly enhanced on pollen presenters while that of $S$. splendens was the same as the control. Knoxdavesia proteae grew significantly faster than $S$. splendens on all tissue types. Despite this, S. splendens was a superior competitor on all tissue types. For K. proteae to co-occupy infructescences with $S$. splendens for extended periods, it likely needs to colonize pollen presenters before the arrival of $S$. splendens and may consequently depend on different spore vectors.

\section{Introduction}

A high diversity of saprobic fungi colonizes senescent plant materials such as leaf litter and wood (Kodsueb et al. 2008) and form integral parts of ecosystem processes such as decomposition and nutrient cycling (Kumar et al. 2012). Many factors contribute to the maintenance of high saprobe diversity on senescent plant parts, including differences in chemical composition and physical structure of different hosts (Lodge et al. 1997; Mille-Lindblom et al. 2006; Paulus et al. 2006; Hyde et al. 2007; Osono 2011; Wolfe and Pringle 2012; Tedersso et al. 2013). However, numerous saprobic fungal species also colonise substrates that originate from a single host and thrive in very close proximity. High numbers of fungal species on senescent parts of the same host may be maintained by differences in nutrient source usage, differences in colonising times related to differences in spore dispersal and differential competitive abilities, all of which may drive succession (Hyde et al. 2007; Bleiker and Six 2009; Zhao et al. 2013; Kubicek et al. 2014). In addition, plant structures usually contain many different tissue types that may each be exploited by different fungi (Hyde et al. 2007; Paulus et al. 2003a, b).

After pollination, the outer involucral bracts of the colourful inflorescences of Protea L. (Proteaceae) enclose the old flowers in compact cone-like infructescences (Fig. 1). Infructescences persist for several years as above-ground seed storage organs (Rebelo 1995) with living tissues comprising only the disclike bases and fertile seeds (Fig. 1). The rest of these structures consist of dead material in the form of hundreds of infertile seeds, bracts, and senescent flower parts (including tepals and pollen presenters). 
Infructescences provide a moist, protected environment (Roets et al. 2012) in which numerous microfungi (Marais \& Wingfield 1994, 2001; Lee et al. 2003, 2005) and arthropods (Coetzee and Giliomee 1987a, b; Roets et al. 2006b) thrive. They represent a unique aerial niche for saprobic fungi that house communities that are strongly divergent from those on senescent Protea twigs and leaves (Lee et al. 2003, 2004; Marincowitz et al. 2008).

Fungi in the genera Knoxdaviesia M.J. Wingf., Van Wyk \& Marasas (Microascales) and Sporothrix M.J. Wingf., Van Wyk \& Marasas (Ophiostomatales) dominate dead floral parts in Protea infructescences (Marais and Wingfield 1994, 2001; Lee et al. 2005; Roets et al. 2005). Three species of Knoxdaviesia (Wingfield et al. 1988; Wingfield and Van Wyk 1993; Crous et al. 2012) and 11 species of Sporothrix (Marais and Wingfield 2001; Roets et al. 2006a, 2008, 2010; Marais and Wingfield 1994, 1997; Ngubane et al. 2017) have been described from this niche. These show various degrees of host recurrence. For example, K. proteae M.J. Wingf., P.S. van Wyk \& Marasas is exclusive to P. repens L. (Roets et al. 2009). In contrast, the closely related $K$. capensis M.J Wingf. \& P.S. van Wyk is common on other host species such as $P$. neriifolia R. Br. and $P$. lauriifolia Thunb. and is only very rarely found on $P$. repens (Roets et al. 2009; Aylward et al. 2015b). Sporothrix splendens G.J. Marais \& M.J. Wingf. is nearly omnipresent within infructescences of $P$. repens, but has occasionally also been found on other hosts such as $P$. neriifolia (Theron-De Bruin et al. 2018). In contrast, S. phasma (Roets, Z.W. de Beer \& M.J. Wingf.) Z.W. de Beer, T.A. Duong \& M.J. Wingf. is found on species such as $P$. neriifolia and $P$. lauriifolia, but never on $P$. repens (Roets et al. 2009). These strong host recurrence patterns are maintained even when the hosts grow sympatrically. It may be ascribed to differences in temperature and humidity within infructescences, differences in chemical composition of different Protea species, host-induced differences in competitive abilities and the actions of their spore vectors (Roets et al. 2012, Mukwevho et al. 2020, 2021).

Knoxdavesia and Sporothrix produce sticky spores adapted to arthropod vectored dispersal (Malloch and Blackwell 1993). Various mites are the primary vectors of all Protea-associated species (Roets et al. 2007, 2009) and some may even have mutualistic associations with their fungal partners (Roets et al. 2007; Theron-De Bruin et al. 2018). For long-distance dispersal, the mites are phoretic on Protea-pollinating beetles (Roets et al. 2008) and birds (Theron-De Bruin et al. 2018). This vectored mode of dispersal not only ensures that these fungi can colonize new flowers over vast distances (Aylward et al. 2014, 2015a, 2016a; Ngubane et al. 2018), but can do so very early on, as soon as the very first flowers open within individual inflorescences (Theron-De Bruin et al. 2018). This gives these competitively weak fungal species an advantage over other saprobic fungi for resources in the restricted infructescence environment (Mukwevho et al. 2021).

Multiple Knoxdavesia and Sporothrix species often grow within the same individual infructescence and even sporulate concurrently (Roets et al. 2005, 2013). Within P. neriifolia infructescences, S. phasma grows on seeds near the base, but also towards the tips of old pollen presenters (Roets et al. 2006a; Theron-De Bruin et al. 2018; Fig. 1). Knoxdaviesia capensis is confined to pollen presenters (Aylward \& Roets pers. observ.). No Knoxdavesia and Sporothrix have been found on the hard P. neriifolia infructescence bases, except if these are damaged by boring insects (Roets et al. 2006). Knoxdavesia and 
Sporothrix in $P$. repens infructescences seem to be more segregated in space, as $K$. proteae is only found on pollen presenters, while $S$. splendens is usually confined to the seeds (Roets et al. 2013). However, $S$. splendens has also been recovered from the involucral bracts that enclose the other floral parts (Fig. 1) and, occasionally, pollen presenters of $P$. repens (Human, Ngubane \& Roets, pers. observ.). This cooccurrence of ecologically similar fungi (in terms of saprobic lifestyle, host recurrence and spore dispersal agents) within the restricted area provided within a single Protea infructescence is intriguing. Possible explanations for this could include differences in position where the different fungi are initially inoculated onto different tissues within infructescences, or that the different fungi may have different competitive abilities on the different tissue types. In terms of the former hypothesis, it is possible that some fungal species outcompete other species only on specific tissue types within infructescences. In terms of the latter hypothesis, inoculation on different tissue types within infructescences is only likely to happen when different fungal species have different main spore vectors.

Protea-associated Sporothrix species are mainly dispersed by mites in the genera Tarsonemus Canestrini and Fonzago, Glycyphagus Hering and Proctolaelaps Ryke between open flowers and by Trichaouropoda Berlese mites between infructescences and open flowers (Roets et al. 2007, 2009, Theron-De Bruin et al. 2018). Main spore vectors for the Knoxdavesia species in this system are not well-studied, but current evidence suggest that they are mainly dispersed by the Trichaouropoda mites between infructescences and open flowers (Roets et al. 2011). Secondary vectors of the Tarsonemus, Glycyphagus and Proctolaelaps mites include various Protea-pollinating insects and birds, while Trichaouropoda mites have only been collected from a single Protea-pollinating beetle species (Roets et al. 2011; Theron-De Bruin et al. 2018).

The present study sets out to test the hypothesis that co-occupancy of individual Protea infructescences by ecologically similar fungi is due to differential competitive abilities on different tissue types within these structures. We test the competitive abilities of $S$. splendens and $K$. proteae on media prepared from bases, pollen presenters, unfertilised seeds and bracts of their usual $P$. repens host. Similarly, the competitive abilities of $S$. phasma and $K$. capensis on media prepared from the bases, pollen presenters and unfertilized seeds from their usual $P$. neriifolia host was tested. Based on field observations, it was expected that no fungi will be able to grow on media prepared from the bases of their hosts. On $P$. neriifolia, it was expected that $S$. phasma can grow on seeds and pollen presenters. Knoxdavesia capensis was expected to only grow on pollen presenters and perhaps on seeds, but if it could grow on seed, it will be outcompeted by S. phasma on this tissue type. As both species often co-occur on pollen presenters, it was expected that they will have similar competitive abilities on these structures. From observations on $P$. repens, it was expected that $S$. splendens will grow on all structures (except infructescence bases) and that $K$. proteae will only be able to grow on media prepared from pollen presenters. If $K$. proteae can grow on media prepared from seeds and bracts, it was expected that $S$. splendens would be a superior competitor. On pollen presenters, $S$. splendens was expected to be a superior competitor (Mukwevho et al. 2021). Any deviations from these expectations may point towards a possible role of different vectors in the dispersal of the various fungal species. 


\section{Methods And Materials}

\section{Collection of fungi and preparation of growth media}

Fungi used in this study were the same species and isolates used in previously published fungal competition studies (Mukwevho et al. 2020, 2021). Knoxdavesia proteae (Stellenbosch Mountain $(-33.9466 ; 18.8805))$ and S. splendens (Betty's Bay (-34.3315 18.9925)) were collected from P. repens and K. capensis (Betty's Bay $(-34.35495 ; 18.90135)$ ) and S. phasma (Jonkershoek Nature Reserve $\left(33^{\circ} 59^{\prime} 24.5^{\prime \prime} \mathrm{S}, 18^{\circ} 57^{\prime} 25.2^{\prime \prime} \mathrm{E}\right)$ ) were collected from P. neriifolia. For growth media (following Roets et al. 2012 and Mukwevho et al. 2020), two-year-old infructescences of $P$. repens and $P$. neriifolia were collected from the Jonkershoek Nature Reserve and air-dried in the laboratory until they opened ca. 3 weeks later. Hereafter infructescences were separated into the infructescence base (receptacle for bracts and florets), the bracts (for $P$. repens only, as the exposed and recurved bracts of $P$. neriifolia are not suitable for colonization by Knoxdavesia and Sporothrix), pollen presenters (including any remnants of tepals) and seeds. For media prepared from seeds, all fertile seeds, identified by their larger size (Theron de-Bruin et al. 2018), were removed as not to include antimicrobial compounds that they may contain into media. These separated dead floral parts were dried at $40^{\circ} \mathrm{C}$ for 48 hours and ground into a fine powder using a milling machine (Monitoring and Control Laboratories (Pty) Ltd). One litre of water-based growth medium contained $300 \mathrm{ml}$ prepared Protea tissue (powder) and $1.5 \%$ MEA. Media was autoclaved at $115^{\circ} \mathrm{C}$ for 20 min and poured into $90 \mathrm{~mm}$ petri dishes that acted as competition arenas (Mukwevho et al. 2021).

\section{Fungal growth rates on different tissues}

The growth of Knoxdavesia and Sporothrix was tested on media prepared from the different tissues following methods described in Roets et al. (2012). In short, plates were centrally inoculated with $5 \mathrm{~mm}$ diameter agar discs containing actively growing, 2-week-old hyphae of one of five different isolates of each of the four fungal species tested ( $n=5$ per tested species on the different media). As we were interested in the growth of the fungi on their usual hosts, S. splendens and K. protea were grown on tissues that originated from $P$. repens and $S$. phasma and $K$. capensis were grown on media prepared from $P$. neriifolia, respectively. In addition, all isolates were also grown on plates containing only MEA as a control. All inoculated plates were inverted and incubated at $25^{\circ} \mathrm{C}$ in the dark. The diameter of each fungal colony on the various media was determined after $10 \mathrm{~d}$ of growth by calculating the average of two perpendicular diameter measurements. Growth for each fungal species on each of the test media was determined by calculating the mean radial growth ( \pm standard error) of the five representative isolates of each of the four fungi. The radial growth for each fungus pair per host species on media from each tissue type were compared using linear models in R ( $R$ Development Core Team, 2013) after log transformation of the data. The model followed the formula: Im (Colony diameter $\sim$ Tissue type + Fungal species + Tissue Type * Fungal species). Hereafter, a conservative Tukey post-hoc test in the R package multcomp was used to determine pairwise differences (Horthawn et al. 2020). Significant differences are reported when $\mathrm{P} \leq 0.05$.

\section{Differential competition between fungi on media prepared from different host tissues}


A de Wit replacement series experimental design (Klepzig and Wilkens 1997; Klepzig 1998) was used to test the competition between $S$. splendens and $K$. proteae (on P. repens infructescence structures) and between S. phasma and $K$. capensis (on $P$. neriifolia infructescence structures) following a modified experimental procedure of Mukwevho et al. $(2020,2021)$. The two competing fungal species were introduced in a $90 \mathrm{~mm}$ diameter plate at different proportions of inoculum and left to compete for available space. Hereafter the total area occupied by each fungus was expressed as a log-linear function of its initial proportion inoculum. If both interacting species had similar competitive abilities, there would be no deviation from linearity. However, significant deviation from linearity for both species, one positive and the other negative, would indicate differential competition with one species dominating over the other. Inoculum covered disks ( $0.5 \mathrm{~mm}$ in diameter) of Knoxdavesia and Sporothrix were aseptically removed from the edges of actively growing fungal colonies and introduced face-down onto plates in a randomised block design ( $4 \times 4 \mathrm{~cm}$ grid) following Mukwevho et al. (2020). Inoculation ratios used included: species A vs. species B: 0:1 (16 disks species B), 0.25:0.75 (4 disks sp. A and 12 disks sp. B), 0.5:0.5 (1:1) (8 disks sp. A and 8 disks sp. B), 0.75:0.25 (12 disks sp. A and 4 disks sp. B) and 1:0 (16 disks species $A$ ). The procedure was repeated for all five tests ( 5 different ratios) per pairwise species combination and replicated five times per tested medium type, each time using different isolates. Plates were incubated at $25 \llbracket \mathrm{C}$ in dark for ten days. Hereafter the areas occupied by each fungus were measured using image $\mathrm{J}$ software (LOCl, University of Wisconsin). Deviations from linearity were calculated by performing an analysis of variance (ANOVA) on log-transformed means of the area data (Wilson \& Lindow 1994) in R (R Development Core Team 2013). Relative crowding coefficients (RCC) were also calculated for all pairwise combinations as [(mean area of species $A$ at $1: 1) /($ mean area of species $A$ at 1:0)] and [(mean area of species $B$ at 1:1)/(mean area of species $B$ at 1:0)]. The interacting species with a higher coefficient is considered as dominant. If the product of the coefficients was one, then fungal competition was neutral. If the product of the coefficients was less than one, then the fungi negatively affect each other and if it was greater than one the taxa benefit from growing together (Willey and Rao 1980).

\section{Results}

\section{Fungal growth rates on different plant tissues}

The model for fungal growth rate of $K$. proteae and S. splendens on the different media types prepared from $P$. repens hosts were significant (F-statistic: 930.9 on 9 and $50 \mathrm{df}$, p-value: <0.001). Similarly, these factors had a significant influence on the growth rate of $G$. capensis and $S$. phasma on media prepared from $P$. neriifolia tissues (F-statistic: 237.6 on 7 and $40 \mathrm{df}$, p-value: $<0.001$ ). Post hoc tests showed that the two fungal species per host plant always differed in their growth rates on the different tissues with the two Knoxdavesia species always outgrowing the Sporothrix species from their respective hosts (Fig. 2). Knoxdaviesia proteae did not grow on media prepared from $P$. repens bases (Fig. 2). It also had a significantly reduced growth rate on media prepared from bracts of this species. It grew well on media prepared from seeds and pollen presenters. As described in Roets et al. (2012), K. proteae produced denser hyphae when growing on media prepared from $P$. repens pollen presenters than on media prepared 
from the seeds and bracts. Sporothrix splendens also failed to grow on media prepared from $P$. repens infructescence bases and its growth rate was supressed on most other infructescence structures. It grew at similar rates on all tissue types of $P$. repens (Fig. 2) and like $K$. proteae, it produced denser hyphae on pollen presenter media than on media prepared from the seeds and bracts. Knoxdaviesia capensis could only grow on media prepared from pollen presenters of $P$. neriifolia (Fig. 2). The growth of $S$. phasma was significantly inhibited on media prepared from $P$. neriifolia infructescence bases. It grew well on seed media, but optimally on pollen presenter media, where it also had the densest colony morphology.

\section{Differential competition between fungi on media prepared from different host tissues}

Differential competition was detected between $K$. proteae and $S$. splendens on $P$. repens pollen presenters, seeds and bracts (Table 1). Sporothrix splendens was always the strongest competitor, as was confirmed also by their relative crowding coefficients. Both fungal species were also always at a disadvantage when competing, as indicated by the product of their respective relative crowding coefficients. Neither $K$. capensis, nor $S$. phasma, was a superior competitor when growing on media prepared from $P$. neriifolia pollen presenters (Table 1). In addition, both species were at a disadvantage when competing on this medium.

\section{Discussion}

Here we provide evidence that factors related to differences in host infructescence tissues help maintain co-occupancy of multiple fungal species with similar ecologies within individual Protea infructescences. This builds on previous data by showing that different senescent structures in plants may each be exploited differentially by different fungal species, leading to enhanced overall biodiversity levels (Paulus et al. 2003a, b; Hyde et al. 2007). However, differences in infructescence tissues did not explain cooccupancy of all fungi tested, and the actions of spore-vectors may also have a significant influence on the persistence of comparatively weaker taxa within this restricted niche. The immense diversity of saprobes in general may therefore be explained by combinations of numerous factors that include host related differences (Hyde et al. 2007; Roets et al. 2012; Mukwevho et al. 2020), differences in substrate colonisation times and differential competitive abilities (Hyde et al. 2007; Bleiker and Six 2009; Zhao et al. 2013; Kubicek et al. 2014).

Results of experimental studies presented here mostly reflected colonization patterns observed in the field. For example, the lack of growth of most fungi on media prepared from infructescence bases was expected from observational studies (Roets et al. 2006; 2013). Sporothrix splendens could grow on all parts of $P$. repens infructescences (except infructescence bases) and $K$. capensis was only able to grow on media prepared from pollen presenters of $P$. neriifolia. Sporothrix phasma, the species with which $K$. capensis mostly shares space within individual $P$. neriifolia infructescences, was able to grow on both the non-fertile seeds and the pollen presenters, confirming field observations (Roets et al. 2006; Theron-De Bruin et al. 2018). Sporothrix phasma and $K$. capensis therefore only compete for resources on pollen presenters, where they have a neutral competitive interaction. A previous study also indicated that both 
species are also able to capture uncolonized space at similar rates when inoculated the same point (i.e., when using the same spore vectors), but importantly, they can maintain this space, as they are not able to overgrow each other (Mukwevho et al. 2020). These data thus neatly explain their co-existence on this $P$. neriifolia resource.

In contrast to the other species evaluated here, $K$. proteae was able to grow on media prepared from infructescence structures of $P$. repens with which it is not known to be associated in field-collected infructescences (i.e., non-viable seeds and bracts). As $S$. splendens can also grow on all structures, $K$. proteae will be in direct competition with $S$. splendens on this host. It is a significantly weaker competitor than $S$. splendens on all these structures, thereby excluding differential competitive abilities as explanation for their co-existence in individual $P$. repens infructescences. Even though a previous study indicated that $K$. capensis can capture at least some space on pollen presenter media when in competition with $S$. splendens, S. splendens would likely eventually overgrow $K$. proteae colonies (Mukwevho et al. 2020). For K. proteae to maintain area within P. repens infructescences for extended periods in the presence of $S$. splendens, it would need to exploit different available nutrient sources than $S$. splendens, or it would need to capture initial space rapidly before colonization by $S$. splendens. Knoxdavesia proteae is known to colonise $P$. repens infructescences at least as early as $S$. splendens and can use Protea nectar sugars as main source when no senescent floral parts are available yet (Aylward et al. 2017). Nutrient sources for $S$. splendens are unknown, but likely include these nectar sugars (Rodriguez-Del Valle et al. 1983), excluding differential nutrient resource usage as explanation for cooccupancy. Knoxdavesia protea is a much faster coloniser of pollen presenter media than S. splendens in the absence of the latter (Roets et al. 2012), but to colonise pollen presenters sooner than S. splendens it would likely also need to rely on a different main vector. Sporothrix splendens is mainly dispersed between inflorescences (flowers) by mites in the genera Tarsonemus, Glycyphagus and Proctolaelaps on Protea pollinating beetles and birds (Roets et al. 2007, 2009; Theron de-Bruin et al. 2018). They may be dispersed from infructescences to inflorescences on Tarsonemus, Proctolaelaps and a Trichaouropoda species vectored by a Protea pollinating beetle (Genuchus hottentottus) (Roets et al. 2007, 2009). Although significantly understudied compared to Sporothrix from this environment, the main vector for $K$. proteae is thought to be the same Trichauropoda mite, but it has also been detected on many other arthropod taxa in infructescences (Roets et al. 2011). Future studies may therefore need to re-examine the main vectors for $K$. proteae considering the evidence presented here.

Interactions with other microbes may help shape the co-occurrence of fungi in individual infructescences. Most other fungal species likely arrive within infructescences after colonization by Knoxdavesia and Sporothrix, and these may have contrasting impacts on the persistence of Knoxdavesia and Sporothrix at a later stage (Mukwevho et al. 2021). Interactions of Knoxdavesia and Sporothrix have been evaluated with very few other fungal taxa to date and only on pollen presenter media. It is possible that an entire network of differential interactions is needed to help maintain the co-existence of multiple fungi in this niche. In addition to fungi, bacteria also abound within these structures, and they can colonise infructescences at a very early stage (Human et al. 2016, 2018, 2021). Many Protea-associated species produce antifungal agents such as fungichromin and actiphenol that inhibit the growth of both 
Knoxdavesia and Sporothrix and other saprobes (Human et al. 2016). It was shown that the Proteaassociated Knoxdavesia and Sporothrix varied in their sensitivity towards these components (Human et al. 2016) and even though no benefit to Knoxdavesia could be deduced, it is possible that fungusbacterial interactions help maintain co-occupancy of multiple Knoxdavesia and Sporothrix taxa in individual Protea infructescences.

\section{Declarations}

\section{Funding}

This project was funded by the DST/NRF Centre of Excellence in Tree Health Biotechnology (CHTB).

\section{Conflicts of interest/Competing interests}

The authors declare that they have no conflict of interest.

\section{Ethics approval}

Not applicable.

\section{Consent to participate}

Not applicable.

\section{Consent for publication}

Not applicable.

\section{Availability of data and material}

Data is available from FR.

\section{Code availability}

Not applicable.

\section{Authors' contributions}

V.O.M: Study design, data collection, laboratory work, statistical analyses, writing of first draft; F.R., L.L.D: Study concept, study design, acquired funding, statistical analyses, writing of manuscript

\section{Acknowledgements}

This project was funded by the Department of Science and Technology (DST) / National Research Foundation (NRF) Centre of Excellence in Tree Health Biotechnology (CHTB). The authors thank the 
South African National Parks Board (SANPARKS) and Western Cape Nature Conservation Board for issuing the necessary collecting permits.

\section{References}

1. Aylward J, Dreyer LL, Steenkamp ET, Wingfield MJ, Roets F (2014). Panmixia defines the genetic diversity of a unique arthropod-dispersed fungus specific to Protea flowers. Ecology and evolution 4(17):3444-3455.

2. Aylward J, Dreyer LL, Steenkamp ET, Wingfield MJ, Roets F (2014) Development of polymorphic microsatellite markers for the genetic characterisation of Knoxdaviesia proteae (Ascomycota: Microascales) using ISSR-PCR and pyrosequencing. Mycological Progress 13(2):439-444.

3. Aylward J, Dreyer LL, Steenkamp ET, Wingfield MJ, Roets F (2015a) Long-distance dispersal and recolonization of a fire-destroyed niche by a mite-associated fungus. Fungal Biology 119(4):245-256

4. Aylward J, Dreyer LL, Steenkamp ET, Wingfield MJ, Roets F (2015b) Knoxdaviesia proteae is not the only Knoxdaviesia-symbiont of Protea repens. IMA fungus 6(2):471-476.

5. Aylward J, Steenkamp ET, Dreyer LL, Roets F, Wingfield BD, Wingfield MJ (2016a) Genome sequences of Knoxdaviesia capensis and K. proteae (Fungi: Ascomycota) from Protea trees in South Africa. Standards in Genomic Sciences 11(1):22.

6. Aylward J, Wingfield BD, Dreyer LL, Roets F, Wingfield MJ, Steenkamp ET (2017) Contrasting carbon metabolism in saprotrophic and pathogenic microascalean fungi from Protea trees. Fungal Ecology 30:88-100.

7. Bleiker KP, Six DL (2009) Competition and coexistence in a multi-partner mutualism: interactions between two fungal symbionts of the mountain pine beetle in beetle-attacked trees. Microbial Ecology 57(1):191-202.

8. Coetzee JH, Giliomee JH (1987a) Seed predation and survival in the infructescences of Protea repens (Proteaceae). South African Journal of Botany 53(1):61-64.

9. Coetzee JH, Giliomee JH (1987b) Borers and other inhabitants of the inflorescences and infructescences of Protea repens in the western Cape. Phytophylactica 19:1-6.

10. Crous PW, Summerell BA, Shivas RG, Burgess TI, Decock CA, Dreyer LL, Granke LL, Guest DI, Hardy GSJ, Hausbeck MK, Hüberli D (2012) Fungal Planet description sheets: 107-127. Persoonia: Molecular Phylogeny and Evolution of Fungi 28:138-182.

11. Hothorn T, Bretz F, Westfall P, Heiberger RM, Schuetzenmeister A, Scheibe S (2020) Multcomp: simultaneous inference in general parametric models. http://multcomp.R-forge.R-project.org

12. Human ZR, Moon K, Bae M, de Beer ZW, Cha S, Wingfield MJ, Slippers B, Oh DC (2016) Antifungal Streptomyces spp. associated with the infructescences of Protea spp. in South Africa. Frontiers in Microbiology 7:1657.

13. Human ZR, Crous CJ, Roets F, Venter SN, Wingfield MJ, de Beer ZW (2018) Biodiversity and ecology of flower-associated actinomycetes in different flowering stages of Protea repens. Antonie van 
Leeuwenhoek, International Journal of General and Molecular Microbiology 111(2):209-226.

14. Human ZR, Roets F, Crous C, Wingfield M, De Beer W, Venter S (2021) Fire impacts bacterial composition in Protea repens (Proteaceae) infructescences. FEMS Microbiology Letters 368(19): fnab132.

15. Hyde KD, Bussaban B, Paulus B, Crous PW, Lee S, Mckenzie EHC, Photita W, Lumyong S (2007) Diversity of saprobic microfungi. Biodiversity and Conservation 16(1):7-35.

16. Klepzig KD, Wilkens RT (1997) Competitive interactions among symbiotic fungi of the southern pine beetle. Applied and Environmental Microbiology 63(2):621-627.

17. Klepzig KD (1998) Competition between a biological control fungus, Ophiostoma piliferum, and symbionts of the southern pine beetle. Mycologia 90(1):69-75.

18. Kodsueb R, McKenzie EHC, Lumyong S, Hyde KD (2008) Diversity of saprobic fungi on Magnoliaceae. Fungal Diversity 30(1):37-53.

19. Kubicek CP, Starr TL, Glass NL (2014) Plant cell wall-degrading enzymes and their secretion in plantpathogenic fungi. Annual Review of Phytopathology 52(1):427-451.

20. Kumar R, Tapwal A, da Silva JA, Baruah DM, Gogoi S (2012) Seasonal dynamics of leaf litter decomposition and fungal population in an undisturbed Dipterocarpus forest of North East India. Tree and Forestry Science and Biotechnology 6(1):130-134

21. Lee S, Groenewald JZ, Taylor JE, Roets F, Crous PW (2003) Rhynchostomatoid fungi occurring on Proteaceae. Mycologia 95(5):902-910.

22. Lee S, Mel'nik V, Taylor JE, Crous PW (2004) Diversity of saprobic hyphomycetes on Proteaceae and Restionaceae from South Africa. Fungal Diversity 17:91-114.

23. Lee S, Roets F, Crous PW (2005) Biodiversity of saprobic microfungi associated with the infructescences of Protea species in South Africa. Fungal Diversity 19:69-78.

24. Lodge DJ (1997) Factors related to diversity of decomposer fungi in tropical forests. Biodiversity and Conservation 6(5):681-688.

25. Malloch D, Blackwell M (1993) Dispersal biology of ophiostomatoid fungi. In: Wingfield M.J., Seifert K.A. Webber J.F., eds. Ceratocystis and Ophiostoma: taxonomy, ecology and pathology. American Phytopathological Socety Press, St. Pauls, MN, USA pp.195-206.

26. Marais GJ, Wingfield MJ (1994) Fungi associated with infructescences of Protea species in South Africa, including a new species of Ophiostoma. Mycological Research 98(4):369-374.

27. Marais GJ, Wingfield MJ (1997) Ophiostoma protearum sp. nov. associated with Protea caffra infructescences. Canadian Journal of Botany 75(2):362-367.

28. Marais GJ, Wingfield MJ (2001) Ophiostoma africanum sp. nov., and a key to ophiostomatoid species from Protea infructescences. Mycological Research 105(2):240-246.

29. Marincowitz S, Crous SW, Groenewald JZ, Wingfield MJ (2008) Microfungi occuring on Proteaceae in the Fynbos. CBS Fungal Biodiversity Centre, Utrecht, Netherlands. 
30. Mille-Lindblom C, Fischer H, Tranvik LJ (2006) Litter-associated bacteria and fungi - A comparison of biomass and communities across lakes and plant species. Freshwater Biology 51(4):730-741.

31. Mukwevho VO, Dreyer LL, Roets F (2020) Interplay between differential competition and actions of spore-vectors explain host exclusivity of saprobic fungi in Protea flowers. Antonie van Leeuwenhoek, International Journal of General and Molecular Microbiology 113: 2187-2200.

32. Mukwevho VO, Dreyer LL, Roets F. (2021) Early colonization of Protea flowers enables dominance of competitively weak saprobic fungi in seed cones, benefitting their hosts. Fungal Biology (in press).

33. Ngubane NP, Dreyer LL, Oberlander KC, Roets F (2018) Two new Sporothrix species from Protea flower heads in South African Grassland and Savanna. Antonie van Leeuwenhoek, International Journal of General and Molecular Microbiology 111(6):965-979.

34. Osono T (2011) Diversity and functioning of fungi associated with leaf litter decomposition in Asian forests of different climatic regions. Fungal Ecology 4(6):375-385.

35. Paulus B, Gadek P, Hyde KD (2003a) Estimation of microfungal diversity in tropical rain forest leaf litter using particle filtration: the effects of leaf storage and surface treatment. Mycological Research 107:748-756

36. Paulus B, Barr ME, Gadek P, Hyde KD (2003b) Three new ascomycetes from a tropical Australian rainforest. Mycotaxon 88:87-96

37. Paulus BC, Kanowski J, Gadek PA, Hyde KD (2006) Diversity and distribution of saprobic microfungi in leaf litter of an Australian tropical rainforest. Mycological Research 110(12):1441-1454.

38. R Development Core Team. 2013. R: A language and environment for statistical computing, $R$ Foundation for Statistical Computing, Vienna, Austria. R Foundation for Statistical Computing, Vienna, Austria.

39. Rebelo T (1995) Proteas of South Africa. Fernwood Press, South Africa.

40. Rodriguez-Del Valle N, Rosario M, Torres-Blasini G (1983) Effects of pH, temperature, aeration and carbon source on the development of the mycelial or yeast forms of Sporothrix schenckii from conidia. Mycopathologia 82(2):83-88.

41. Roets F, Dreyer LL, Crous PW (2005) Seasonal trends in colonisation of Protea infructescences by Gondwanamyces and Ophiostoma spp. South African Journal of Botany 71(3-4):307-311.

42. Roets F, Dreyer LL, Geertsema H, Crous PW (2006b) Arthropod communities in Proteaceae infructescences: seasonal variation and the influence of infructescence phenology. African Entomology 14(2):257-265.

43. Roets F, Wingfield MJ, Dreyer LL, Crous PW, Bellstedt DU (2006) A PCR-based method to detect species of Gondwanamyces and Ophiostoma on surfaces of insects colonizing Protea flowers. Canadian Journal of Botany 84(6):989-994.

44. Roets F, De Beer ZW, Dreyer LL, Zipfel R, Crous PW, Wingfield MJ (2006a) Multi-gene phylogeny for Ophiostoma spp. reveals two new species from Protea infructescences. Studies in Mycology 55:199212. 
45. Roets F, Wingfield MJ, Crous PW, Dreyer LL (2007) Discovery of fungus-mite mutualism in a unique niche. Environmental Entomology 36(5):1226-37.

46. Roets F, de Beer ZW, Wingfield MJ, Crous PW, Dreyer L (2008) Ophiostoma gemellus and Sporothrix variecibatus from mites infesting Protea infructescences in South Africa. Mycologia 100(3):496-510.

47. Roets F, Crous PW, Wingfield MJ, Dreyer LL (2009) Mite-mediated hyperphoretic dispersal of from the infructescences of South African Protea spp. Environmental Entomology 38(1):143-152.

48. Roets F, Wingfield MJ, Crous PW, Dreyer LL (2009) Fungal radiation in the Cape Floristic Region: an analysis based on Gondwanamyces and Ophiostoma. Molecular Phylogenetics and Evolution 51(1):111-119.

49. Roets F, Wingfield BD, de Beer ZW, Wingfield MJ, Dreyer LL (2010) Two new Ophiostoma species from Protea caffra in Zambia. Persoonia: Molecular Phylogeny and Evolution of Fungi 24:18-28.

50. Roets F, Wingfield MJ, Wingfield BD, Dreyer LL (2011) Mites are the most common vectors of the fungus Gondwanamyces proteae in Protea infructescences. Fungal Biology 115(4-5):343-350.

51. Roets F, Theron N, Wingfield MJ, Dreyer LL (2012) Biotic and abiotic constraints that facilitate host exclusivity of Gondwanamyces and Ophiostoma on Protea. Fungal Biology 116(1):49-61.

52. Roets F, Wingfield MJ, Crous PW. Dreyer LL (2013) Taxonomy and ecology of ophiostomatoid fungi associated with Protea infructescences. In: Seifert, K.A., de Beer, Z.W., Wingfield, M.J. (Eds), Ophiostomatoid fungi: Expanding Frontiers. CBS Biodiversity Series, Utrecht, The Netherlands, pp.177-187.

53. Tedersoo L, Mett M, Ishida TA, Bahram M (2013) Phylogenetic relationships among host plants explain differences in fungal species richness and community composition in ectomycorrhizal symbiosis. New Phytologist 199(3):822-831.

54. Theron-De Bruin N, Dreyer LL, Ueckermann EA, Wingfield MJ, Roets F (2018) Birds mediate a fungusmite mutualism. Microbial Ecology 75(4):863-874.

55. Willey RW, Rao MR (1980) A competitive ratio for quantifying competition between intercrops. Experimental Agriculture 16(2):117-125.

56. Wingfield MJ, Van Wyk PS (1993) A new species of Ophiostoma from Protea infructescences in South Africa. Mycological Research 97(6):709-716.

57. Wingfield BD, Viljoen CD, Wingfield MJ (1999) Phylogenetic relationships of ophiostomatoid fungi associated with Protea infructescences in South Africa. Mycological Research 103(12):1616-1620.

58. Wingfield MJ, Van Wyk PS, Marasas WFO (1988) Ceratocystiopsis proteae sp. nov., with a new anamorph genus. Mycologia 80(1):23-30.

59. Wolfe BE, Pringle A (2012) Geographically structured host specificity is caused by the range expansions and host shifts of a symbiotic fungus. ISME Journal 6(4):745-755.

60. Zhao Z, Liu H, Wang C, Xu JR (2013) Comparative analysis of fungal genomes reveals different plant cell wall degrading capacity in fungi. BMC Genomics 14(1):274. 


\section{Table}

Table 1: ANOVA statistics for tests of deviation from linearity in relationships between the areas occupied by competing fungal species in a de Wit replacement series on media prepared from senescent tissues within infructescences of $P$. repens and $P$. neriifolia. The competitive influence of each separate species in an interacting pair, or relative crowding coefficient (RCC) and the product of the RCC values of the interacting pairs (in brackets) are also provided. $d f=$ Degrees of freedom, SS = Sum of squares, MS = Mean square 


\begin{tabular}{|c|c|c|c|c|c|c|c|}
\hline Comparison & Source & $d f$ & SS & MS & $\mathrm{F}$ value & $P$ value & $\mathrm{RCC}$ \\
\hline \multicolumn{8}{|c|}{ On $P$. repens pollen presenters } \\
\hline S. splendens vs K. proteae & & & & & & & $(0.257)$ \\
\hline \multirow[t]{2}{*}{ S. splendens area } & Proportion & 3 & 0.09 & 0.030 & 22.54 & $<0.001$ & 0.675 \\
\hline & Residual & 11 & 0.01 & 0.001 & & & \\
\hline \multirow[t]{2}{*}{ K. proteae area } & Proportion & 3 & 0.16 & 0.055 & 8.33 & 0.005 & 0.381 \\
\hline & Residual & 10 & 0.07 & 0.007 & & & \\
\hline \multicolumn{8}{|l|}{ On $P$. repens bracts } \\
\hline K. proteaevs S. splendens & & & & & & & $(0.212)$ \\
\hline \multirow[t]{2}{*}{ K. proteae area } & proportion & 3 & 0.50 & 0.167 & 4.80 & 0.034 & 0.296 \\
\hline & Residual & 8 & 0.28 & 0.035 & & & \\
\hline \multirow[t]{2}{*}{ S. splendens area } & proportion & 3 & 1.03 & 0.344 & 457.30 & $<0.001$ & 0.717 \\
\hline & Residual & 8 & 0.01 & 0.001 & & & \\
\hline \multicolumn{8}{|l|}{ On $P$. repens seeds } \\
\hline K. proteaevs S. splendens & & & & & & & $(0.175)$ \\
\hline \multirow[t]{2}{*}{ K. proteae area } & Proportion & 3 & 0.65 & 0.218 & 17.32 & $<0.001$ & 0.335 \\
\hline & Residual & 10 & 0.13 & 0.013 & & & \\
\hline \multirow[t]{2}{*}{ S. splendens area } & Proportion & 3 & 1.59 & 0.529 & 177.6 & $<0.001$ & 0.523 \\
\hline & Residual & 10 & 0.03 & 0.003 & & & \\
\hline \multicolumn{8}{|c|}{ On $P$. neriifolia pollen presenters } \\
\hline S. phasma vs K. capensis & & & & & & & $(0.222)$ \\
\hline \multirow[t]{2}{*}{ S. phasma area } & Proportion & 1 & 0.01 & 0.002 & 0.35 & 0.567 & 0.041 \\
\hline & Residual & 12 & 0.07 & 0.006 & & & \\
\hline \multirow[t]{2}{*}{ K. capensis area } & Proportion & 1 & 0.00 & 0.000 & 0.03 & 0.864 & 0.547 \\
\hline & Residual & 10 & 0.07 & 0.006 & & & \\
\hline
\end{tabular}

\section{Figures}



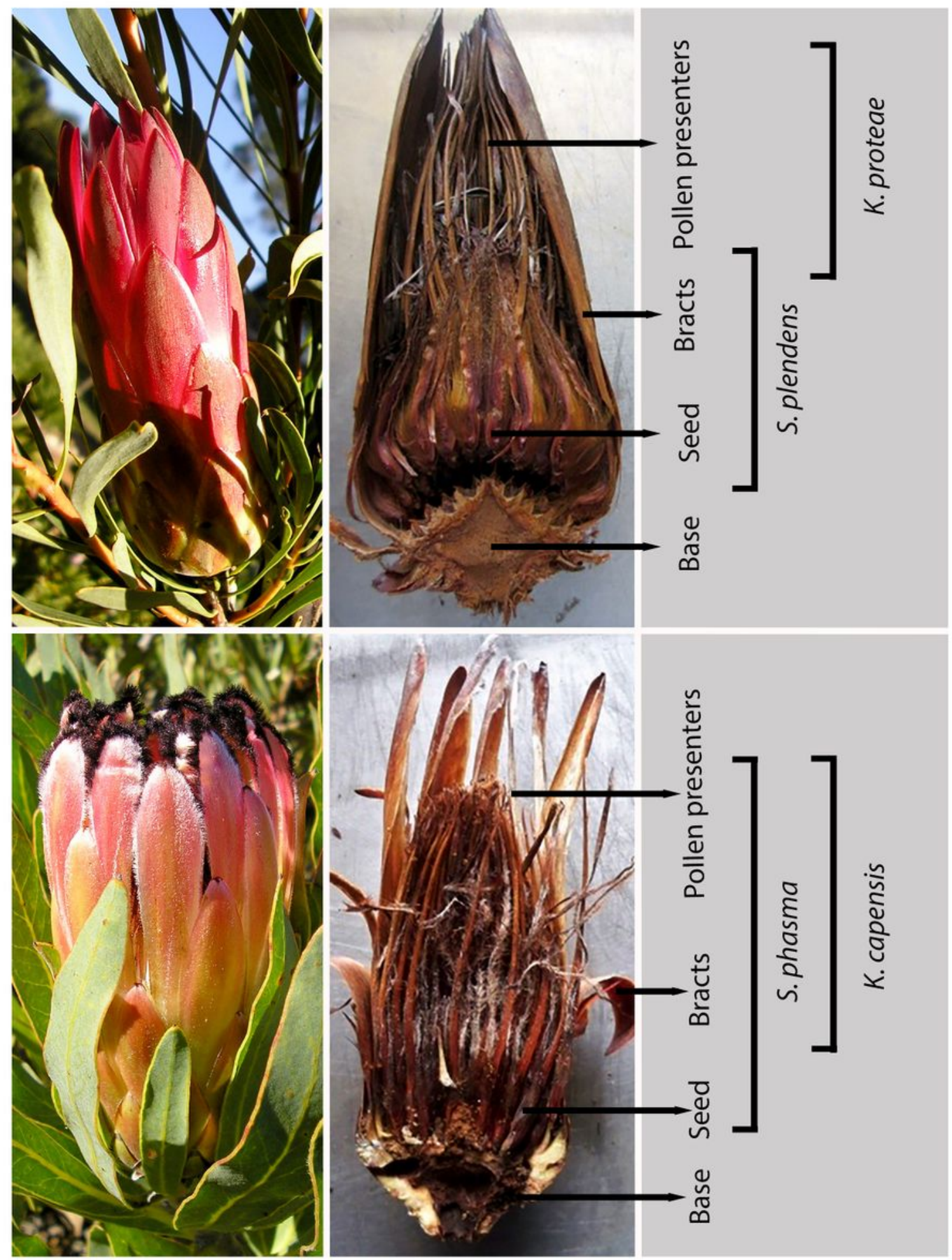

\section{Figure 1}

(Top left) - Inflorescence of Protea repens, (Top middle) - cross-section of Protea repens infructescence showing the hard receptacle (base) at the bottom with attached seeds, extended pollen presenters, and the surrounding bracts. Areas occupied by S. splendens (seeds, bracts and occasionally also pollen presenters) and $K$. proteae (pollen presenters) are indicated at the top right. (Bottom left) - inflorescence of Protea neriifolia, (Bottom middle) - cross-section of $P$. neriifolia infructuscence showing the hard base 
at the bottom with attached seeds, extended pollen presenters, and the recurved bracts. Areas occupied by S. phasma (seeds and pollen presenters) and K. capensis (pollen presenters) are indicated at the top right.

Protea repens

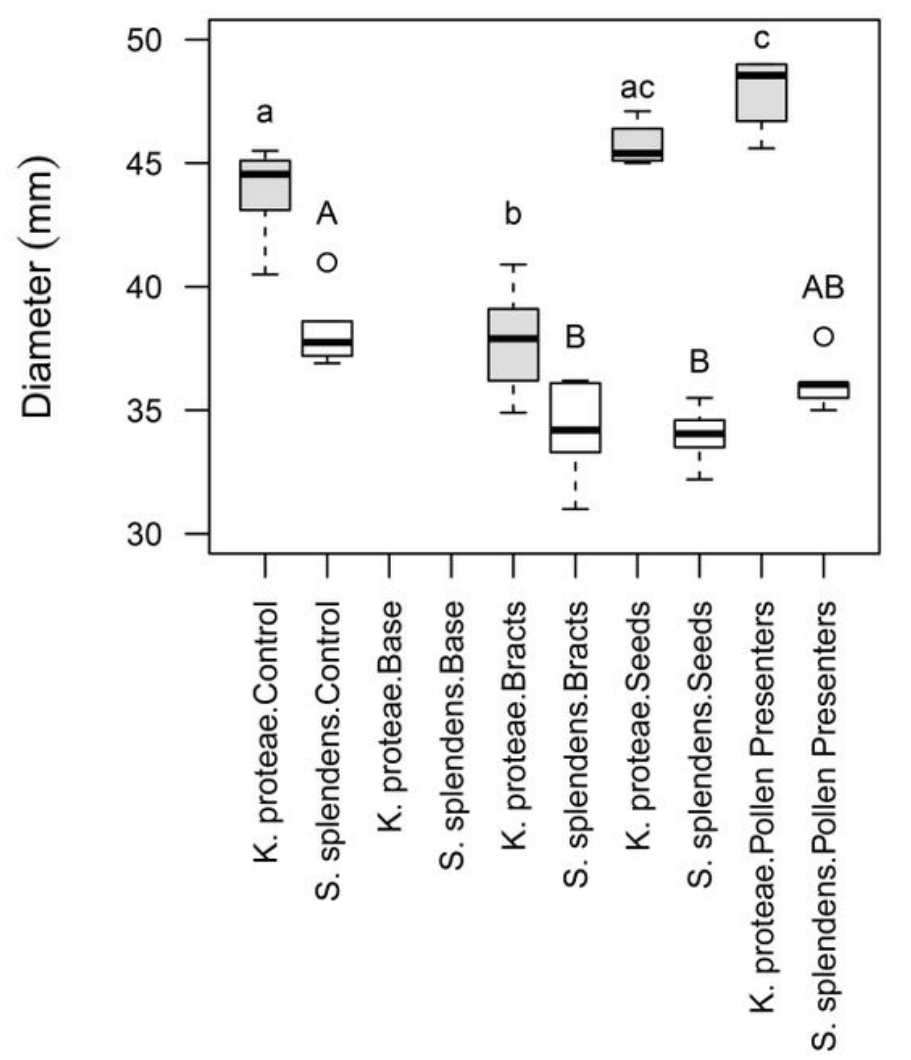

Protea neriifolia

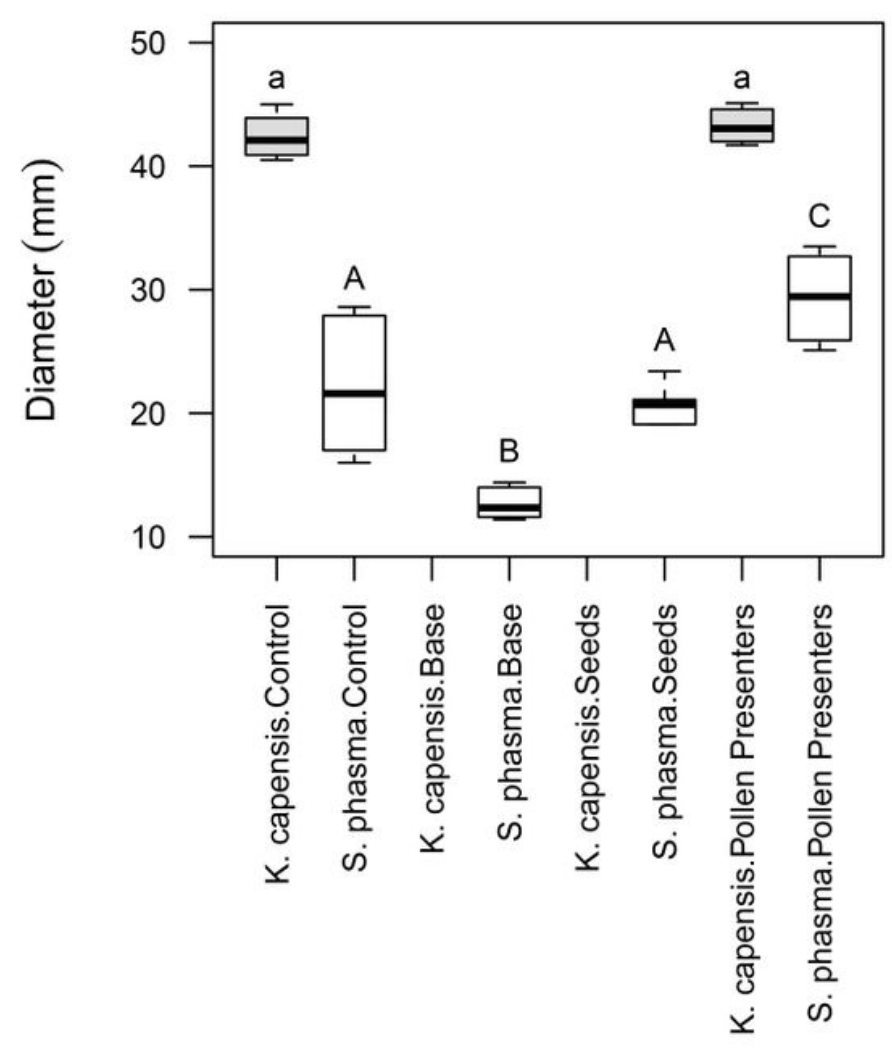

\section{Figure 2}

Mean radial growth ( $\mathrm{mm}$ diameter after $10 \mathrm{~d}$ at $25^{\circ} \mathrm{C}$ ) of $K$. proteae, K. capensis (in grey bars) and $S$. phasma and $S$. splendens (in white bars) on media prepared from senescent tissues from the infructescences of $P$. repens (left) $P$. neriifolia (right) respectively. Controls consisted of malt extract agar only. Boxes indicate $25-75 \%$ data range, whiskers indicate 1.5 times the interquartile range and dots represent outliers. Different letters above bars denote significant differences per media type for the respective fungal species (lower case for the two Knoxdavesia species and upper case for the two Sporothrix species). For both comparisons, the Knoxdavesia species always had significantly larger colony diameters than the Sporothrix species on all tissue types (not indicated on the graphs). 